\title{
The Impact of Cash Management Practices toward Financial Performance of Small and Medium Enterprises in Indonesia
}

\author{
Nuzulia Amini ${ }^{\mathrm{a}}$, Bambang Setiono ${ }^{\mathrm{b}}$, Christian Haposan Pangaribuan ${ }^{\mathrm{c}}$, Elfindah Princes ${ }^{\mathrm{d}}$ \\ a, b, c Sampoerna University, Jakarta, Indonesia \\ ${ }^{\mathrm{d}}$ The University of Queensland, Brisbane, Australia
}

\begin{abstract}
Objective - The importance of SMEs in Indonesia has been becoming the center of attention for the government to help the national economy grow. However, there are still many problems that hinder the potential of SMEs to develop. One of the problems is financial Management in terms of cash management, which can help SMEs have better Management over cash and better performance. Therefore, this study aims to analyze the current two elements of cash management practice, forecasting (FOR) and cash mobilization (CML) done by SMEs in Indonesia and its impact on Return on Assets (ROA) and Gross Profit Margin (GPM) as the financial performance measurements.

Methodology - The research uses a quantitative approach from 90 SMEs in Java and Bali islands from April until July 2018. The data were analyzed descriptively using a 4-point scale questionnaire. A regression analysis was added to find out significant relationships between the variables.

Findings - The research found that SMEs owners/managers often do forecasting and rarely do cash mobilization practices. The regression analysis shows a significant relationship between cash management practices and ROA but a non-significant relationship between cash management practices and Gross Profit Margin (GPM).

Novelty - This research provides an insight of how cash management practices influence the financial performance in the context of SMEs.

Keywords: Small and Medium Enterprises; Cash Management; Forecasting; Cash Mobilization; Financial Performance

JEL Classification: G00, D00, M13

Article info: Received 10 March 2021; Revised 3 April 2021; Accepted 10 May 2021

Article Correspondence: christian.pangaribuan@sampoernauniversity.ac.id

Recommended Citation: Amini, N., Setiono, B., Pangaribuan, C. H., \& Princes, E. (2021). The Impact of Cash Management Practices toward Financial Performance of SMEs in Indonesia. Journal of Business, Management, and Social Studies, 1(1), 35-47.
\end{abstract}

\section{INTRODUCTION}

In recent decades, small business has played an essential role in spurring global economic growth due to its job creation ability. The importance of small and medium enterprises affects the flourishing economic prosperity of the most developing country and the developed continent such as the US and Europe. The data from SBA Office of Advocacy (2018) showed that US SMEs successfully employed $48 \%$ of the private workforce and results in strengthening the US economy for a $1.9 \%$ annual rate in 2015. Simultaneously, this good progress is also happening in Europe, where SMEs have employed 90 million people and are successful in generating added value as much as 3.9 trillion euro (Muller et al., 2016).

Indonesian government is actively promoting the importance of entrepreneurship by making several programs to trigger the society doing business and focusing on efforts to empower small-medium enterprises (Melissa et al., 2015). According to an Antara News (2020) report, the small business sector in Indonesia has contributed $61.7 \%$ of the state's gross domestic product (GDP). However, this good news cannot guarantee that there is no weakness among the SMEs in Indonesia. As a matter of fact, the growth of total SMEs in Indonesia is not followed by the growth of the performance itself. Figure 1 shows the growth of total employee that work in SMEs. During the last five years, from 2009 until 2013, the ability 
of SMEs to absorb the workforce keeps increasing. The biggest rise happened at $6 \%$ or equal to $114,144,082$ employees in 2013. However, the growth of its contribution toward national GDP is exceptionally fluctuating. The increasing growth only lasts up to the year 2011 at $6.76 \%$. Meanwhile, the growth keeps decreasing from $6 \%$ in 2012 to $5.89 \%$ in 2013.

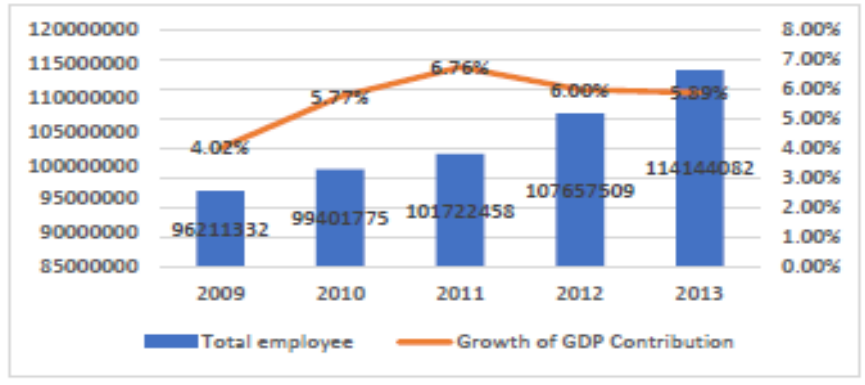

Badan Pusat Statistik, 2016)

Figure 1. The Growth of SMEs Workforce (Badan Pusat Statistik, 2016)

The data indicate that SMEs in Indonesia are still facing some difficulties that make their performance seen from its contribution growth to GDP decreases. Several factors still become the concern of SMEs in Indonesia. The study from Adawiyah (2013) proves that SMEs' most inhibiting factor in developing is dominantly due to lack of financial support. Most SMEs in Banyumas rely on personal savings as a source of capital. Suci (2017) revealed that the weaknesses faced by SMEs in Indonesia in improving business capability are very complex, with one of the indicators is due to lack of financial support. Meanwhile, the previous study from Indarti and Langenberg (2004) revealed that the ease of access of financial resources is one of the success factors of the SME itself.

Furthermore, Suryani et al. (2016) explained that lack of financial capability potentially leads SMEs in Indonesia to face failures toward performance and growth. Financial capability is a composite of an individual's knowledge, skill, and understanding to manage finance, including the ability to act according to the firm's financial circumstances. Thus, the financial capability of SME owners or manager will affect their ability to do financial management. Under this research, financial management is observed based on their knowledge of financial basic, saving/deposit, investment, insurance, and risk management. Although the result shows that SMEs have understood the importance of financial management, many still lack understanding because most SMEs do not have optimal investment decisions. The study also revealed that SMEs with better financial capability would become more likely to achieve better performance such as sales and profit growth because they performed better financial management. This conclusion indicates that the problems with low performance are because of the inability to manage finances and technology that inhibits them from doing financial records.

Hidayat (2015) argues that entrepreneurial incompetence causes the most impactful factor contributing to small businesses' failures in Cimahi. The entrepreneurial competence itself is related to several aspects such as human resources management, financial management, and creativity. The financial management aspect focused on the ability to do financial control, recording, financial resources, and also control on receivables. Another study from Aufar (2013) said that one of the main factors resulting in failure is the incapability of using accounting information, including how the business can perform financial accounting, management accounting, and cost accounting. All these aspects deal with how the transaction is recorded and how cash is allocated for production. Through a descriptive study, it was understood that certain factors such as educational background affects the inability both to create and utilize the accounting information. Ali and Kodrat (2017), in their latest study, also revealed that their case-study research on one of SMEs proves that one of SMEs' biggest failures is strategy and communication. The strategic factor deals with how the manager prepares its plan for the future operation that needs a resource allocation. In this case, budget preparation is needed to make the plan for resource allocation. Budget preparation is part of cash 
management practices that explain how the owner/manager could allocate costs for future needs. This research supports a study from Anton et al. (2015) in three different clusters in Indonesia. They found that SMEs' ability in managing working capital management could improve business performance. However, the study also revealed that $80 \%$ of respondents could not get financial support from a bank as a capital source because they failed to compile the financial plan or budgeting. Capital constraint could affect potential growth of small businesses (Pangaribuan et al., 2018).

The reason behind the hesitation of a financial institution like a bank to give a loan to an SME is due to its bad cash management that could contribute to the risk of bad debt. In general, banks need SME financial statement as one of credit filling requirements (Azis \& Rusland, 2009). According to Pandey (2020), small firms' failure is due to inadequate cash management. Indonesia's Central Bank report about "Business Profile of Micro, Small, and Medium Enterprises" (2015) also says that many SMEs in Indonesia still have weaknesses in many aspects, including the accountability that emphasizes the financial administration system management. Therefore, the practice of cash management is crucially needed for SMEs. Cash management practice will help SMEs to get financial support, create better performance, and better decision-making (Murwanto et al., 2006). The previous studies' research gap reveals to how extensive the SMEs in Indonesia have implemented financial management. Therefore, this study aims to fulfill this research gap. Furthermore, this study will also figure out the relation between cash management practice to SMEs' financial performance because effective cash management is a fundamental standing point to ensure the strong position of a firm's financing (Thevaruban, 2016). Besides, this study underlines the trade-off theory of liquidity. It explains that a firm should optimize liquidity to balance the benefit and cost of holding cash and thus could have better performance.

\section{LITERATURE REVIEW}

\section{Definitions of SMEs}

Since the term small-medium enterprises (SMEs) has been broadly defined, most countries in the world tend to determine their small-medium enterprises' definition under the law. It is because each country adjusts the definition of SMEs based on their economic condition. In Indonesia, the definition and detail information about SMEs have been varying across different institutions. A study from Suryani et al. (2016) prefers to define SMEs in Indonesia based on Indonesian Government Law no.20 in 2008. SMEs have several criteria that classify them into micro-business, small, or medium businesses. Small enterprises have total net assets of more than 50 million rupiahs up to 500 million rupiahs, excluding land and building for the business purpose and annual total sales of from 300 million rupiahs to 2.5 billion rupiahs. Meanwhile, medium enterprises are defined as a business with total net assets from 500 million rupiahs to 10 billion rupiahs, excluding land and building for business purposes with annual total sales from 2.5 billion rupiahs to 50 billion rupiahs.

\section{The Trade-Off Theory of Liquidity}

This study used the trade-off theory of liquidity proposed by Modigliani and Miller (1958) as the framework. This theory explains that a firm should target an optimal level of liquidity to balance the cost and benefit of holding cash to increase the firm's growth and performance. The example of cost for holding cash can derive from the low-rate return of the asset and the possibility of tax loss. On the other hand, the benefit of holding cash is two-fold where the company can save the cost to raise funds and have sufficient funding or payment without liquidating their assets. As the importance of liquidity is highly asserted, there must be an effort to maintain the liquidity, especially for small businesses struggling to grow. In response, cash management practice is needed as the central importance of cash management is to maintain the firm's liquidity. By implementing cash management practice, a firm can pay its short-term obligation as they come due and finance day-to-day operations (Diacogiannis, 1994). Besides, Moyer et al., (2005) specifically said that cash management would help small businesses to increase their growth of sales that require cash 
resource to increase receivables and inventories. Therefore, this study wants to examine the impact of effective cash management practice as a tool to maintain liquidity on small business performance.

\section{Business Environment}

SMEs have become the backbone for most countries to increase their national income. Many actions have been utilized to support SMEs' improvement in Indonesia, both from the government and academicians. From the perspective of academicians, many had tried to analyze SMEs' business environment, which some of it has become constraints that SMEs generally face. Abdullahi et al. (2015) argued that most SMEs are owner-centered, where the owner is the primary decision-maker for general business practices, including the day-to-day operation. Since the owner is the primary source of decisionmaking, SMEs' decision type follows the owner's experiences and characteristics (Hamza et al., 2015). Moreover, good decision-making is supposed to be taken by gathering adequate information to provide possible alternatives decisions and not based on some known facts only (Ahmed \& Omotunde, 2012). For example, to address the liquidity crisis issue, SMEs have to look at their financial report to identify the root of the problem. The alternatives decision can be formed either has to reduce production cost or take some loan from the bank.

Further, Hessel and Parker (2013) argue that SMEs are more likely to have lacked capital and human resources, which has also become a constraint faced by SMEs to grow. The low number of human resources will make it hard for SMEs to manage their operation well especially when the employees have a low level of managerial training and skills (Cacciolatti \& Lee, 2015). Lekhanya (2016) also stated that SMEs, dominated mainly by owner-manager authority, lack the necessary skills and capabilities to build a start-up business and operations. Due to this incapability of management skills, especially in financial Management, SMEs are perceived to have higher credit and operational risks that restrain them from getting financial access (Andrikopoulos \& Khorasgani, 2018). Credit risk on SMEs is related to the risk of SMEs not able to pay back the loan. Besides, the treatment in giving loans from banks to SMEs has to be distinguished from a more prominent firm (Jindrichovska, 2013). In SMEs, banks need to work harder to assess the credit risk of SMEs because the information needed for the assessment is often not available. For example, a study from McCann and McIndoe-Calder (2012) tried to find a model which Bank can use in assessing the credit risk such as default risk attach to SMEs. However, this was not successful due to SMEs' information opacity, such as the unavailability of balance sheets or market outcome-based data. The bank must understand its characteristics since the owner influences credit risk in having appropriate and effective credit management (Jindrichovska, 2013). With better credit management, the credit risk will be lower.

Peel and Wilson (1996) posited that poor financial management has also made SME a typical business with less liquid with a more fluctuate profit and cash flow measures than larger businesses. In addition, the smaller business tends to expand their credit sales although there is no sufficient cash to fund the expansion. Meanwhile, this condition can make the business run out of cash because SMEs cannot finance the operation since there is no reserved cash and most of the sales income is in the form of receivable.

\section{Cash Management}

The firm uses cash to make purchases and payments. Business companies need cash to acquire both tangible and intangible assets used for production. However, success is not counted according to how much money it has in its bank account. The management over the cash is what all matters. In real cases, if the cash is well managed, the business leaders can decide the purchased inventories decision under the amount of cash owned (Tennent, 2012). For example, if a business analyzes its report and conclude that they do not have much money, they will tend to purchase cheaper goods or purchase products in lesser amount. According to Deb et al. (2015), cash management refers to the managing of cash balances held by a firm at a specific time, cash flow within the firm, and cash flow into and out of the firm. Meanwhile, Steiss and Nwagwu (2001) emphasize that cash management is focused on revenues and expenditures to avoid three potential problems: liquidity crisis, bad debt expenses, and abundant idle cash balances. This research 
examines two elements of cash management, forecasting and cash mobilization as two main elements in cash management.

First, forecasting is focused on a presupposition about the most significant impact that could occur in the future based on the current, relatable conditions. In cash management, forecasting has been used as the appropriate guidance of reasonable control over the organization's cashflow. Forecasting helps organizations explain movements in economic time series reflected in the form of trend or business cycle (Nibbering et al., 2018). Forecasting also helps owner/manager to avoid 'surprise' toward condition such as the unexpected cash deficit or surpluses (Warren \& Barnes, 2003). Meanwhile, the cash deficit or cash surpluses may be seen from cash balances which will be nearly impossible if there is no such budgeting record in the organizations (Attom, 2012). Moreover, many external stakeholders, like the investors, always look into the budget to forecast the future of the organization. Fay and Patterson (2018) argue that budget also will enable the internal stakeholder such as manager or owner to prepare a financial statement as budgeted income statement, balance sheet, and cash flow statement. Budget is about the overall summary of planned expense and revenue or, in the simplest term, a budget is the future saving and spending. It shows how organizations create their future expenditures and how much they will earn in return. Budget is crucial as part of forecasting because it provides the report of cost allocation plan so that managers can measure the firm's liquidity because liquidity refers to conditions where business able to pay expenses and liabilities, hence, very crucial for business survival and growth (Attom, 2012).

Second, cash mobilization is part of the total review of cash management so that an organization could obtain faster information to execute any excess cash (Finnerity, 2006). Cash mobilization has been divided into two major aspects of function: acceleration of receivables and acceleration of disbursement. Further, a firm is expected to emphasize four objectives of the daily transaction:

(1) Accelerating Collections: The collection is one activity that every firm should do to get their receivables paid off by third parties. This activity is crucial since receivable has a risk of being uncollected. Receivable has been part of organizations revenue when some products or services have been offered through credit payment. If a firm cannot collect its revenue as soon as possible, the firm will be hard to get enough cash to finance other operations activities. It will be even worse if the major revenue comes from credit selling since the risk of uncollectible receivables will even higher. In evidence, Agyei-Mensah (2010) argue that in an attempt to have higher sales, SME tends to have much willingness to extend credit to their buyer without knowing the credit risk level attached to them, which may cause a default. Meanwhile, the receivable may become an exclusive concern for the business growth. Therefore, an activity to control any credit is considered fundamental for small business to reduce default, affecting lower income. The credit control itself may be done by speeding up the collection of accounts receivable. Gitman et al. (1979) show that this practice has become one of the most critical cash management practices for a business. Besides, Dalton (2007) emphasizes that getting paid sooner from customers can be one way to make a cash flow recovery. In conclusion, the accelerating collection helps get additional cash and increase income.

(2) Controlling Disbursement of Fund: The payment decision is vital because it will affect the liquidity of the organizations. Gitman et al. (1979) found that larger firms tend to do slowing payment rather than the smaller firms, which put less emphasis on this area. It will enable the company to optimize earnings on the available fund by delaying cash outflows. Therefore, good cash management practices are supposed to manage that disbursement is made when it is due. However, this activity sometimes could be tough to be implemented. As a result, two approaches can be used (Steiss \& Nwagwu, 2001). The company can centralize its payable, especially those which involve a large amount of money. This can be done using the centralized depository account. Another approach is establishing an administrative limit for any organizational cash outflow within a certain period that can be realized through a zero-balancing system. However, these practices may not be visible for SMEs since they still have small numbers of suppliers and customers to centralize deposits like most of the larger firms. Instead, Oluoch (2016) argued that using holding cash (cash reserved) that can be made through budgeting will benefit SMEs in how one of them is controlling payment. Besides, by keeping all the transaction records such as invoices, the company could 
control when the latest payment is due, and a budget for cash outflow could be made to exercise the payment and prevent inappropriate use of funds (Al-Smirat, 2016).

(3) Controlling Over Bank Balance: To manage the bank balance, a firm should have a bank account and regularly maintain it. A study from Hamza et al. (2015) found that most SMEs in developing countries such as Ghana maintained their bank account to increase the chances of getting a bank loan. Furthermore, this will allow small business to minimize the tendency of cash shortage and make monthly reconciliation between the bank balance and the cash book (Ahmad, 2016).

(4) Investment of Cash Surplus: A business must be aware that they should minimize the amount of cash surplus by transforming it into something more profitable. It can be converted into more valuable resources such as fixed assets or investment channels. Several studies have utilized this practice as a reflection of good management practices for SMEs. However, the importance of this practice is still less considered by small businesses. A study from Enow and Kamala (2016) revealed that most South African SMEs have low intention to invest their cash surplus in short-term or long-term investment and even put the cash surplus into a bank deposit. Ahmad (2016) then found a high percentage of SMEs in Malaysia holding cash surplus, which indicates small investment. Putting the cash surplus into bank deposits will allow SMEs to get an additional return from the interest.

\author{
Hypothesis 1 (H1): The interaction between Forecasting (FOR) and Cash Mobilization (CML) \\ influences Return on Assets (ROA). \\ Hypothesis 2 (H2): The interaction between Forecasting (FOR) and Cash Mobilization (CML) \\ influences Gross Profit Margin (GPM). \\ Hypothesis 3 (H3): Forecasting (FOR) influences Return on Assets (ROA). \\ Hypothesis 4 (H4): Cash Mobilization (CML) influences Return on Assets (ROA).
}

\title{
III. RESEARCH METHODOLOGY
}

This study uses quantitative approach to test the impact of SMEs' cash management practices on their financial performance. The data were collected in 2018 using a questionnaire in two formats, open and close-ended questionnaires. The close-ended used a four Likert scale. The survey design is cross-sectional as to examine a particular phenomenon at a point in time, representing the objective of this study to figure out the SMEs' current management practices in Indonesia. The secondary data measured SMEs' financial performance through their financial statements. Since the study is conducted using survey design, the cash management practice will be analyzed using the descriptive statistic derived from the survey result. This is needed as the study tries to answer whether SMEs in Indonesia perform proper cash management practices and what kind of management practices it is. Meanwhile, the multiple regression test will be used to know the degree of correlation or the significance between cash management practices and financial performance. The samples are the SMEs in Java and Bali obtained from Bank Indonesia's database. However, due to lack of significant responses, the researcher also collected the data by directly coming to the SMEs to obtain the response more effectively. Overall, there are 90 samples used in this study.

\section{FINDINGS AND DISCUSSION}

From the survey, the distribution of the respondents is mostly from West Java with 30 respondents (33\%) and followed by Central Java with 28 respondents (31\%), East Java with 16 respondents (18\%), Special Region Yogyakarta with 10 respondents (11\%), and Bali with 6 respondents (7\%). For the respondent's position in the business, the result shows that 73 respondents $(81 \%)$ are business owners. Only 9 respondents (10\%) are full-time accountants, 5 respondents $(6 \%)$ are managers, and 3 respondents (3\%) are part-time accountants. The respondents are mostly undergraduates (45.6\%), master's degree (5.6\%), high 
school graduates (34.4\%), elementary school (2.2\%), and middle school (12.2\%). Furthermore, the respondent business profile shows that almost 85 respondents (94\%) are sole proprietorships, four respondents $(5 \%)$ are in the form of $\mathrm{CV}$, and one respondent (1\%) is a corporation. The survey reveals majority of the respondents in this research are start-up businesses where $61 \%$ of the business has been established for 0-5 years. Moreover, the respondents who are self-employed is 13 respondents (14\%), employ 1-5 people is 61 respondents (68\%), employ 6-10 people is nine respondents (10\%), employ 11-15 people is six respondents (7\%), and employ more than 15 persons is one respondent (1.1\%). Lastly, majority of respondents confirm that their businesses include trading, hotel, and restaurant business for 45 respondents (50\%), agricultural, farms, and fisheries (1\%); manufacturing (12\%); electricity, gas, and clean water (1\%); transportation and communication (1\%); Finance, rental, and company services (2\%); and others (33\%). As this research seeks to understand the extent of SMEs in Indonesia in doing their cash management practice, the explanation of the survey result is presented particularly in terms of forecasting and cash mobilization, as an element of effective cash management.

Table 1. Frequency of occurrence of Variable X1 (Forecasting)

\begin{tabular}{|c|c|c|c|c|c|c|c|c|c|}
\hline \multirow[t]{2}{*}{ Forecasting (X1) } & \multicolumn{2}{|c|}{$\begin{array}{c}\text { Never } \\
1\end{array}$} & \multicolumn{2}{|c|}{$\begin{array}{c}\text { Rarely } \\
2\end{array}$} & \multicolumn{2}{|c|}{$\begin{array}{c}\text { Often } \\
\mathbf{3} \\
\end{array}$} & \multicolumn{2}{|c|}{$\begin{array}{c}\text { Always } \\
4\end{array}$} & \multirow[t]{2}{*}{ Mean } \\
\hline & Freq. & $\%$ & Freq. & $\%$ & Freq. & $\%$ & Freq. & $\%$ & \\
\hline Cash Budget Preparation & 12 & 13 & 22 & 24 & 22 & 24 & 34 & 38 & 2.87 \\
\hline Cash Inflow Supervision & 2 & 2 & 6 & 7 & 23 & 26 & 59 & 66 & 3.54 \\
\hline $\begin{array}{c}\text { Cash outflow } \\
\text { Supervision }\end{array}$ & 4 & 4 & 11 & 12 & 29 & 32 & 46 & 51 & 3.30 \\
\hline Cash Balance Control & 3 & 3 & 9 & 10 & 24 & 27 & 54 & 60 & 3.43 \\
\hline
\end{tabular}

The variable Forecasting (X1) are constructed from four items which are cash budget preparation, cash inflow supervision, cash outflow supervision, and control over bank balance. Table 1 shows the descriptive result over this four-item of variable forecasting (X1). The table shows that the respondent often makes cash budget preparation because the weighted average is 2.87 or equal to 3 (often). Furthermore, it was found that the reason why 34 respondents (37\%) never or rarely prepare cash budget is that $41 \%$ of respondents did not need it, $21 \%$ of respondents had no idea about budgeting, $14 \%$ of respondents said cash budget was not applicable for their business, $12 \%$ could not make it, and $12 \%$ of respondents had no time for preparing cash budget. The table also reveals that the respondents know how much money inflows to the business since the weighted average of their response is 3.54 (in the scale of 4). The majority respond that they always do cash inflow control by $66 \%$ (59 respondents). In addition, $51 \%$ of the response says they always supervise their cash outflow with the weighted average response is equal to 3.30 (answer between scale 3-4), which means they often control their cash flow. It can be concluded that SMEs in Indonesia tend to have balance knowledge toward the cash inflow rather than cash outflow. Besides, the average result of respondent control over their cash balance shows the value of 3.43, which means that they often maintain and control their cash balance. It can be concluded that the respondent often does forecasting because the overall weighted average of this variable is 3.29 or equal to 3 (often).

For X2 variable (Cash Mobilization), nine items are used to describe this variable. Compared to the forecasting, respondent has lower cash mobilization practice occurrence. SMEs in Indonesia have rarely been trying to accelerate the collection of its receivable where only 24 respondents (27\%) claimed that they always try to collect their receivable as soon as possible. Contradictory, SMEs in Indonesia have made a sufficient effort regarding the management control over the disbursement where $69 \%$ of the respondents always pay the liability on time, with $59 \%$ of them also pay debts on time. From this standpoint, although the respondent seems to have balance control over the cash inflow and outflow in the forecasting section, the extended effort to maintain it is better on the disbursement (cash outflow) with a weighted average of 3.56. The respondent also proved to have a slight tendency to hold too much cash (cash surplus), where only nine respondents (10\%) claim to have a cash surplus. Simultaneously, more than $70 \%$ of respondents 
also rarely invest their money in financial assets or other physical assets whenever they have a cash surplus. As a result, SMEs' cash mobilization in Indonesia as one of the elements of effective cash management practice is still low since the overall weighted average of this variable is 2.73 (scale 2-3).

Table 2. Frequency of occurrence of Variable X2 (Cash Mobilization)

\begin{tabular}{|c|c|c|c|c|c|c|c|c|c|}
\hline \multirow[t]{2}{*}{ Cash Mobilization } & \multicolumn{2}{|c|}{$\begin{array}{c}\text { Never } \\
1\end{array}$} & \multicolumn{2}{|c|}{$\begin{array}{l}\text { Rarely } \\
\quad 2\end{array}$} & \multicolumn{2}{|c|}{$\begin{array}{c}\text { Often } \\
3\end{array}$} & \multicolumn{2}{|c|}{$\begin{array}{c}\text { Always } \\
4\end{array}$} & \multirow[t]{2}{*}{ Mean } \\
\hline & Freq. & $\%$ & Freq. & $\%$ & Freq. & $\%$ & Freq. & $\%$ & \\
\hline Acceleration on $\mathrm{A} / \mathrm{R}$ collection & 25 & 28 & 22 & 24 & 19 & 21 & 24 & 27 & 2.47 \\
\hline Liability disbursement & 1 & 1 & 10 & 11 & 17 & 19 & 62 & 69 & 3.56 \\
\hline Records kept on Cash Transaction & 8 & 9 & 16 & 18 & 14 & 16 & 52 & 58 & 3.22 \\
\hline Savings maintained & 5 & 6 & 19 & 21 & 29 & 32 & 37 & 41 & 3.09 \\
\hline Bank Account maintained & 13 & 14 & 21 & 23 & 17 & 19 & 39 & 43 & 2.91 \\
\hline Cash surplus & 21 & 23 & 35 & 39 & 25 & 28 & 9 & 10 & 2.24 \\
\hline $\begin{array}{c}\text { Investment cash surplus on financial } \\
\text { instrument }\end{array}$ & 48 & 53 & 29 & 32 & 5 & 6 & 8 & 9 & 1.70 \\
\hline Investment cash surplus on physical asset & 27 & 30 & 38 & 42 & 16 & 18 & 9 & 10 & 2.08 \\
\hline Debt payment & 8 & 9 & 10 & 11 & 19 & 21 & 53 & 59 & 3.30 \\
\hline
\end{tabular}

The dependent variable is the financial performance of the SMEs. Specifically, the financial performance measure used in this study is the profitability measure of ROA and gross profit margin. From the analysis, table 3 shows the mean ROA of the respondent is equal to 0.3824. It means that the SMEs can generate profit from its asset by as much as $38 \%$. Besides, the overall weighted mean for the gross profit margin is equal to 0.5060 . This result indicates that the SMEs have $50 \%$ of gross profit from their net sales. According to Leach \& Melicher (2009), SMEs' financial performance in Java and Bali is in a good condition because the ROA $>25 \%$ and gross profit margin $>50 \%$ are considered to have high attractiveness in highperformance ventures.

Table 3. Descriptive Statistic Result of Variable Y (Financial Performance)

\begin{tabular}{cccccc}
\hline & N & Minimum & Maximum & Mean & Std. Deviation \\
\hline ROA & 90 & 0.00 & 1.00 & 0.3824 & 0.25493 \\
Gross Profit Margin & 90 & 0.00 & 0.96 & 0.5060 & 0.21152 \\
Valid N (listwise) & 90 & & & & \\
\hline
\end{tabular}

Table 4 shows the summary model of multiple linear regression results which focuses on ROA as the dependent variable $(\mathrm{Y})$. The $\mathrm{R}^{2}$ of the model explaining the collaborative relationship between the independent variables (FOR and CML) toward the dependent variable is $12 \%$. Although the $\mathrm{R}^{2}$ of the first model is below $50 \%$, this does not indicate that the relationship is inherently wrong. This study is trying to analyze respondents' cash management practices. Such data may vary from one respondent to another, which makes it has low $\mathrm{R}^{2}$. Therefore, the $\mathrm{R}^{2}$ is still statistically significant for the researcher to conclude the relationship between the variables. Moreover, the adjusted $\mathrm{R}^{2}$ value of this model is $10 \%$, meaning that the influence factor of the independent variables (FOR and CML) toward the dependent variable (ROA) is $10 \%$. Meanwhile, the rest $90 \%$ is influenced by other factors not explained in this study. For the model of multiple regression itself, the model built by the researcher is significant because the value is 0.004 or less than alpha 0.05 and the F-statistic > F-table $(5.937>3.11)$. This indicates that the independent variables (FOR and CML) simultaneously influence the dependent variable of (ROA) and thus, HO is rejected. The result is presented in Table 4.

H1: The interaction between Forecasting (FOR) and Cash Mobilization (CML) influences Return on Assets $(R O A) \rightarrow$ ACCEPTED 
Table 4. Model Summary Table of Multiple Linear Regression (ROA)

\begin{tabular}{|c|c|c|c|c|}
\hline Model & $\mathbf{R}$ & $\mathbf{R}^{2}$ & Adjusted R $\mathbf{R}^{2}$ & Std. Error of the Estimate \\
\hline 1 & $0.347 *$ & 0.120 & 0.100 & 0.24187 \\
\hline
\end{tabular}

Table 5. ANOVA Table of Multiple Linear Regression (ROA)

\begin{tabular}{cccccc}
\hline Model & Sum of Squares & Df & Mean Square & F & Sig. \\
\hline Regression & 0.695 & 2 & 0.347 & 5.937 & $0.004^{\mathrm{b}}$ \\
Residual & 5.090 & 87 & 0.059 & & \\
Total & 5.784 & 89 & & & \\
\hline a. Dependent Variable: ROA & & & & \\
b. Predictors: (Constant), CML, FOR & & & &
\end{tabular}

Table 6 is the model summary for the second model where gross profit margin (GPM) becomes the dependent variable toward FOR and CML as independent variables. The value of $\mathrm{R}^{2}$ is $20 \%$ indicating that the independent variables (FOR and CML) represent the dependent variable (GPM) as much as $20 \%$. However, the adjusted $\mathrm{R}^{2}$ of this model shows a negative value. Meaning that there is very low goodness of fit in which FOR and CML are insignificant explanatory variable for the dependent variable (GPM). As a result, the significance of the model shown in Table 7 is low because the value is bigger than alpha 0.05 for 0.420 . Moreover, the value of F-statistic < F-table $(0.877<3.11)$ thus, $\mathrm{H} 0$ is accepted.

H2: The interaction between Forecasting (FOR) and Cash Mobilization (CML) influences Gross Profit $\operatorname{Margin}(G P M) \rightarrow$ REJECTED

Table 6. Model Summary Table of Multiple Linear Regression (GPM)

\begin{tabular}{|c|c|c|c|c|}
\hline Model & $\mathbf{R}$ & $\mathbf{R}^{2}$ & Adjusted R $\mathbf{R}^{2}$ & Std. Error of the Estimate \\
\hline 1 & $0.141^{*}$ & 0.020 & -0.003 & 0.21181 \\
\hline
\end{tabular}

Table 7. ANOVA Table of Multiple Linear Regression (GPM)

\begin{tabular}{cccccc}
\hline Model & Sum of Squares & df & Mean Square & F & Sig. \\
\hline Regression & 0.079 & 2 & 0.039 & 0.877 & $0.420^{\mathrm{b}}$ \\
Residual & 3.903 & 87 & 0.045 & & \\
Total & 3.982 & 89 & & & \\
\hline a. Dependent Variable: ROA & & & & \\
b. Predictors: (Constant), CML, FOR & & & &
\end{tabular}

The result is quite different when the dependent variable is ROA. This may occur because of the difference in accounting report methodology where income (sales) can be written in two different forms: cash basis or accrual basis. According to Motto et al. (2017), SMEs in Indonesia have been trying to move the recording process based on an accrual basis instead of a cash basis. Moreover, cash management practice focuses on the management over cash which the collection and disbursement of physical cash are different from the recording. Therefore, the possibility of cash management practice influences the gross profit margin decreases.

In terms of the regression model, the independent variables, cash mobilization and forecasting have significant relationships with ROA but not with GPM. Thus, the second model cannot be used. From the multiple regression coefficients result in table 8, the coefficient of FOR (forecasting) variable is 0.789 with a t-statistic value is 0.779 . The t-table value at a significance level of 0.05 is 1.990 . As a result, this research 
fails to reject $\mathrm{H} 0$ because the t-statistic < t-table $(0.779<1.990)$ means there is no relationship between forecasting and variable ROA.

H3: Forecasting (FOR) influences Return on Assets (ROA) $\rightarrow$ REJECTED

Table 8. Coefficient Table of Multiple Regression (ROA)

\begin{tabular}{cccccccc}
\hline \multirow{2}{*}{ Model } & \multicolumn{2}{c}{$\begin{array}{c}\text { Unstandardized Coefficients } \\
\text { B }\end{array}$} & $\begin{array}{c}\text { Standardized Coefficients } \\
\text { Std Error }\end{array}$ & $\begin{array}{c}\text { t } \\
\text { Beta }\end{array}$ & \multicolumn{2}{c}{ Sig. } & $\begin{array}{c}\text { Collinearity Statistics } \\
\text { Tolerance } \\
\text { VIF }\end{array}$ \\
\hline (Constant) & 0.789 & 0.173 & & 4.561 & 0.000 & \\
Forecasting & 0.035 & 0.045 & 0.084 & 0.779 & 0.438 & 0.879 \\
Cash Mobilization & -0.191 & 0.056 & -0.367 & -3.418 & 0.001 & 0.879 & 1.138 \\
\hline
\end{tabular}

However, the multiple regression results in Table 8 show the regression coefficient value of variable Cash Mobilization (CML) equal to -0.191 with a t-test value of -3.418 in which it is bigger than the t-table ($3.418>-1.990)$. As a result, the $\mathrm{H} 0$ is rejected, meaning there is a linear relationship between cash mobilization (CML) toward the ROA.

\section{H4: Cash Mobilization (CML) influences Return on Assets $($ ROA) $\rightarrow$ ACCEPTED}

From the analysis result of multiple regression, the structural equation for the model is written as:

$*$ ROA $=0.789+0.035$ FOR $-0.191 \mathrm{CML}^{*}$

$*=$ significance level $5 \%$

In Table 8, variable CML has the most significant value below the fair value $(\alpha=0.05)$ toward the ROA as one of the financial performance measures in terms of profitability. This significance is influenced by the researcher's questions, such as acceleration on the receivable, bank account maintenance, investment on cash surplus, and disbursement control, constructed into a nine-item of list question. However, the relationship of variable CML toward ROA is negative, meaning that SMEs with lower cash mobilization will be more likely to have a higher impact on the ROA. In other words, the more SMEs owner/manager hold their cash within the firm, the more ROA there will be. The high cash mobilization may decrease the ROA because there are two proxies that represent cash mobilization in terms of investment on cash surplus. Horne \& Wachowicz (2008) explained that the least likely firm invests their cash surplus, the bigger the opportunity lost to generate more profit from the assets themselves (the investment). As a result, the ROA will decrease. Besides, the low investment also indicates that there is a possibility of a high occurrence of excess cash, which also may result in lower ROA. This is because the high excess cash will lead managers to invest it below the cost of capital or waste it on company inefficiency instead of productive purpose (Zaheer, 2017). Moreover, although the variable of forecasting (FOR) has a positive coefficient in this model, it has no significant correlation toward ROA. This result is different compared to the previous study from Hamza et al. (2015), Olouch (2016), and Al-Smirat (2016) because they used different proxies to measure the financial performance of the SMEs.

\section{CONCLUSION}

The survey result of cash management practices shows that SME owners/managers are aware of the basics of cash management because the weighted average of respondents shows good value for forecasting practice and cash mobilization. The degree of SMEs in forecasting is between often and always while cash mobilization between rare and often with cash inflow supervision as the dominant practice that more often to be done. This indicates that SMEs currently has a deeper concern in term of forecasting rather than cash mobilization. In forecasting, cash inflow supervision has become the dominant action for SMEs 
owner/manager without making the budget preparation. SMEs still have low awareness of this practice because $41 \%$ say they do not need it for this time.

Although the SME owners/managers have deep concern about the cash inflow, they also have a good understanding of the importance of not being delinquent for any liability. It shows that liability and debt disbursement control have become the dominant practice that reflects cash mobilization. Furthermore, SMEs' owners/managers also maintain their bank account and work hard to accelerate their receivables. Unfortunately, the understanding of respondents in optimizing cash surplus through investment still low.

In conclusion, from all these practices, the regression result found out that the overall cash management practice only has a relationship toward financial performance (ROA) instead of gross profit margin. Besides, the variable that has a significant effect is only the cash mobilization, while forecasting has no impact on the ROA. This finding does not support the previous studies by Hamza et al. (2015), Olouch (2016), and Al-Smirat (2016) but strengthens the past research by John (2014), Saluja and Kumar (2012), and Abioro (2013), in which liquidity tend to have a negative influence on profitability especially on ROA, where cash management acts as one of the instruments to support and maintain the liquidity of the company. Lastly, there is a negative-significant relation between cash management practice and financial performance (ROA), it is recommended for SMEs owner-manager to maintain equilibrium between the cash management practice and the financial performance itself. There are several recommendations for future research. First, the scope of study should be wider. Second, the float control as one of the cash management variables should be included in the future study to see whether any different outcome can be derived to improve this research finding.

\section{REFERENCES}

Abdullahi, M. S., Abubakar, A., Aliyu, R. L., Umar, K., Umar, M. B., Sabiu, I. T., .\& Abubakar, L. S. (2015). The Nature of Small and Medium Scale Enterprises (SMEs): Government and Financial Institution Support in Nigeria. International Journal of Academic Research in Business and Social Sciences, 5(3), 525-537.

Abioro, M. (2013). The impact of cash management on the performance of manufacturing in Nigeria. Uncertain Supply Chain Management, 1(2013), 177-192.

Adawiyah, W. R. (2011). Faktor Penghambat Pertumbuhan Usaha Mikro Kecil Menengah (UMKM): Studi di Kabupaten Banyumas, 1(1), 1-18.

Agyei-Mensah, B. K. (2010). Working Capital Management Practices of Small Firms in the Ashanti Region of Ghana. International Journal of Academic Research in Business and Social Sciences, 2(1), 567-583.

Ahmad, N. N. (2016). Cash Management Practices in Micro and Small Businesses in Malaysia. Journal of Education and Social Science, 4(June), 331-335.

Ahmed, M. T. \& Omotunde, H. (2012). Theories And Strategies of Good Decision Making. International Journal of Science \& Technology Research, 1(10), 51-54.

Al-Smirat, B. Y. (2016). Cash Management Practices and Financial Performance of Small and Medium Enterprises (SMEs) in Jordan. Cash Management Practices and Financial Performance of Small and Medium Enterprises (SMEs) in Jordan, 7(2), 98-107.

Ali, M. Y. \& Kodrat, D. S. (2017). Faktor-faktor Penyebab Kegagalan Bisnis Pada Perusahaan Mitra Jaya Abadi. Jurnal Manajemen dan Start-Up Bisnis, 2(1), 124-131.

Andrikopoulos, P., \& Khorasgani, A. (2018). Predicting unlisted SMEs' default: Incorporating market information on accounting-based models for improved accuracy. The British Accounting Review, 50(5), 559-573.

Anton, S. A., Muzakan, I., Muhammad, W. F., Syamsudin, \& Sidiq, N. P. (2015). An Assessment of SME Competitiveness. Journal of Competitiveness, 7(2), 60-74.

Attom, B. E. (2012). Cash Management Practices By Micro And Small-Scale Enterprises At Kasoa In The Central Region of Ghana. Asian Journal of Business and Management Sciences, 3(02), 1-12.

Aufar, A. (2013). Faktor-faktor yang mempengaruhi penggunaan informasi akuntansi pada UMKM. Universitas Widyatama.

Antara News (2020). BKPM sebut UMKM sumbang PDB sebesar 61,7 persen. Retrieved from https://www.antaranews.com/berita/1794321/bkpm-sebut-umkm-sumbang-pdb-sebesar-617-persen

Azis, A. \& Rusland, A. H. (2009). Peranan Bank Indonesia di Dalam Mendukung Perkembangan Usaha Mikro, Kecil, dan Menengah. Pusat Pendidikan dan Studi Kebanksentralan (PPSK). 
Badan Pusat Statistik (2016, December 22). Tabel Perkembangan UMKM pada Periode 1997 -2013. Retrieved from Badan Pusat Statistik: https://www.bps.go.id/linkTabelStatis/view/id/1322

Cacciolatti, L. \& Lee, S. H. (2015). Entrepreneurial Marketing for SMEs. Springer.

Dalton, T. (2007). Cash Management: Making your business cash-rich without breaking the bank. A \& C Black Publishers, Ltd.

Deb, G., Dey, N. B., \& Shil, P. (2015). Cash Management Practices in Micro and Small Enterprises in Barak Valley: An Analytical Study. Sai Om Journal of Commerce \& Management: A Peer-Reviewed International Journal, 2(2), $1-10$.

Diacogiannis, G. (1994). Financial Management: A Modelling Approach Using Spreadsheets. McGraw-Hill.

Enow, S. T. \& Kamala, P. (2016). Cash management practices of small, medium and micro-enterprises in the Cape Metropolis, South Africa. Investment Management and Financial Innovations, 13(1), 230-236.

Fay, J. J. \& Patterson, D. (2018). Contemporary Security Management. Butterworth-Heinemann.

Finnerty, J. E. (2006). Working Capital and Cash Flow. In C.-F. Lee, A.C. Lee, J. Lee (eds.), Encyclopedia of Finance (1st ed.). Springer.

Gitman, L. J., Moses, E. R., \& White, J. T. (1979). An Assessment of Corporate Cash Management Practices. Financial Management, Spring(1979), 32-41.

Hamza, K., Mutala, Z., \& Antwi, S. K. (2015). Cash Management Practices and Financial Performance Of Small And Medium Enterprises (SMEs) In The Northern Region Of Ghana. International Journal of Economics, Commerce and Management, 3(7), 456-480.

Hessels, J. \& Parker, S. C. (2013). Constraints, internationalization and growth: A cross-country analysis of European SMEs . Journal of World Business, 48(1), 137-148.

Hidayat, A. W. (2015). Identifikasi factor internal dan eksternal penyebab kegagalan usaha pada industry tahu di kelurahan Citeureup kota Cimahi (Studi kasus pada usaha tahu di kampung Sukaresmi tahun 2014). e-Proceeding of Management, 2(1), 53-60.

Horne, J. C. \& Wachowicz, J. M. (2008). Fundamentals of Financial Management $\left(13^{\text {th }}\right.$ ed.). Pearson Education Limited.

Indarti, N. \& Langenberg, M. (2004). Factors Affecting Business Success Among SMEs: Empirical Evidences From Indonesia. The Second Bi-Annual European Summer University. Netherland: University of Twente, Enschede.

Jindrichovska, I. (2013). Financial Management in SMEs. European Research Studies, XVI(Special Issue on SMEs), 81-96.

John, A. O. (2014). Effect of cash management on firm profitability of Nigerian manufacturing firms. International Journal of Technology Marketing, 4(1), 129-140.

Leach, J. C. \& Melicher, R. W. (2009). Entrepreneurial Finance, 4th Edition. Cengage Learning.

Lekhanya, L. M. (2016). Business characteristics of small and medium enterprises in rural areas: a case study on southern region of KwaZulu-Natal province of South Africa. Problems and Perspectives in Management, 14(3), 108-114.

McCann, F. \& McIndoe-Calder, T. (2012). Determinants of SME Loan Default: The Importance of Borrower-Level Heterogeneity. Central Bank of Ireland conference: The Irish SME Lending Market: Descriptions, Analysis, Prescriptions, March 2 ${ }^{\text {nd }}, 2012$.

Melissa, E., Hamidati A., Saraswati M.S., \& Flor A. (2015) The Internet and Indonesian Women Entrepreneurs: Examining the Impact of Social Media on Women Empowerment. In: Chib A., May J., Barrantes R. (eds) Impact of Information Society Research in the Global South. Springer, Singapore.

Modigliani, F. \& Miller, M. H. (1958). The Cost of Capital, Corporation Finance and the Theory of Investment. The American Economic Review, 48(3), 261-297.

Motto, A., Ilat, V., \& Kalalo, M. (2017). Penerapan Akrual Basis Pada Pelaporan Keuangan UMKM Bedasarakan ETAP di Koperasi Karyawan PT Bank Sulut. Going Concern: Jurnal Riset Akuntansi, 12(2), 1151-1157.

Moyer, R. C., McGuigan, J., \& Kretlow, W. (2005). Contemporary Financial Management. South-Western.

Muller, P., Devnani, S., Julius, J., Gagliardi, D., \& Marzocchi, C. (2016). Annual Report on European SMEs 2015/2016. Europe: European Unions. Retrieved from https://ec.europa.eu/jrc/sites/jrcsh/files/annual_report__eu_smes_2015-16.pdf

Murwanto, R., Insyafiah, \& Subkhan. (2006). Manajemen Kas. Lembaga Pengkajian Keuangan Publik dan Akuntansi Pemerintah (LPKPAP).

Nibbering, D., Paap, R., \& van der Wel, M. (2018). What do professional forecasters actually predict? International Journal of Forecasting, 34(2), 288-311. 
Oluoch, J. O. (2016). The Impact of Cash Management Practices on Performance of SMEs: A Survey of SMEs in Eldoret Central Business District. IOSR Journal of Economics and Finances, 7(6), 1-7.

Pandey, D. L. (2020). Impact of Cash Management on Profitability in Small Manufacturing Organization. Silver Jubilee Issue PRAVAHA, 25(1), 53-58.

Pangaribuan, C. H., Putra, O. P. B., Lesthary, L., Aguzman, G., \& Hidayat, D. (2018). The Analysis of Potential Growth for Indonesia's Micro Small Medium Business Owners. International Journal of Business Studies, 2(2), 62-73.

Peel, M. J., \& Wilson, N. (1996). Working Capital and Financial Management Practices in the Small Firm Sector. International Business Journal, 14(2), 52-68.

Saluja, P., \& Kumar, D. P. (2012). Liquidity and Profitability Trade-off. International Journal of Advanced Research in Management and Social Sciences , 1(3), 77-84.

SBA Office of Advocacy (2018). 2018 Small Business Profile. Retrieved from https://www.sba.gov/sites/default/files/advocacy/2018-Small-Business-Profiles-US.pdf

Statistik, B. P. (2016, December 22). Tabel Perkembangan UMKM pada Periode 1997 -2013. Retrieved from https://www.bps.go.id/statictable/2014/01/30/1322/tabel-perkembangan-umkm-pada-periode-1997--2013.html

Steiss, A. W., \& Nwagwu, E. O. (2001). Financial Planning and Management in Public Organizations. Marcel Dekker Inc.

Suci, Y. R. (2017). Perkembangan UMKM (Usaha Mikro Kecil dan Menengah) di Indonesia. Jurnal Ilmiah Cano Ekonomos, 6(1), 51-58.

Suryani, T., Iramani, R., \& Lindiawati. (2016). Exploring Financial Capabilities of SMEs and Improving Financial Management Performance Using Financial Application. International Journal of Management and Applied Science, 3(2), 79-83.

Tennent, J. (2012). Guide to Cash Management. Profile Books, Ltd.

Thevaruban, J. S. (2016). Impact of Cash Management on Financial Performance of the Sri Lankan Manufacturing Company. EPRA International Journal of Economic and Business Review, 4(8), 118-126.

Warren, K. \& Barnes, C. (2003). The Impact of GAAP on Fiscal Decision Making: A Review of Twelve Years' Experience with Accrual and Output-based Budgets in New Zealand. OECD Journal on Budgeting, 3(4), 7-40.

Zaheer, S. (2017). The Effect of Excess Cash Holding on the Value of the Firm and Stock Returns. (Unpublished master's thesis). Capital University of Science and Technology, Islamabad, Pakistan. 